\title{
Response of Muskmelon to Spectral Modification of Shading Nets under Different Drip Irrigation Regimes
}

\author{
A.D. Utkhede ${ }^{1 *}$, S.B. Gadge ${ }^{2}$ and S.D. Gorantiwar ${ }^{3}$
}

Department of Irrigation and Drainage Engineering, Dr. A. S. College of Agriculture

Engineering and Tech., Mahatma Phule Krishi Vidyapeeth, Rahuri-413 722, India

*Corresponding author

\begin{tabular}{|l|}
\hline K e y w o r d s \\
Muskmelon \\
(Cucumis melo). \\
$\begin{array}{l}\text { Shading net, } \\
\text { Evapotranspiration, } \\
\text { Yield }\end{array}$ \\
\hline Article Info \\
\hline $\begin{array}{l}\text { Accepted: } \\
\text { 04 January } 2019 \\
\text { Available Online: } \\
\text { 10 February } 2019\end{array}$ \\
\hline
\end{tabular}

\section{Keywords}

Shading net,

Evapotranspiration,

Article Info

Accepted:

Available Online:

10 February 2019

\section{A B S T R A C T}

A field experiment on muskmelon crop was carried out at the instructional farm of department of Irrigation and Drainage Engineering, Dr. A.S.C.A.E.\&T., Mahatma Phule Krishi Vidyapeeth, Rahuri, Maharashtra, during the period February- June, 2017, to study the response of shading nets and different irrigation regimes on yield of muskmelon (Cucumis melo L.). The experiment was laid in split factorial design with five main treatment (green white shade net with 35, 50\&75\% shading, red shade net with $50 \%$ shading and open field) and eight irrigation sub treatment. The sub treatments comprised of four levels of irrigation $\left(120,100,80,60 \%\right.$ of $\mathrm{ET}_{\mathrm{c}}$ ) with and without silver black plastic mulch, respectively. Each sub treatment was replicated thrice in individual shade net house and the open field. Irrigation was scheduled on the basis of reference crop evapotranspiration estimated by Penman- Monteith's method. The water soluble fertilizer viz., 19:19:19 and urea was applied in 25 split, 15 days after sowing. The seasonal water requirement of muskmelon crop, water use efficiency, fertilizer use efficiency, yield, benefit cost ratio, and biometric observation was recorded and statistically analyzed. The performance of crop grown inside shading nets (red and green white shading net) was comparatively better than the open field. Maximum yield $\left(10.41 \mathrm{t}^{-\mathrm{ha}^{-1}}\right)$ was observed under red shade net with $50 \%$ shading with application of drip irrigation @ $120 \%$ of $^{2} T_{c}$ under silver black plastic mulch during summer season. The results shall be helpful to the farmers interested in muskmelon cultivation under semi-arid conditions of Maharashtra state.

\section{Introduction}

Muskmelon (Cucumis melo L.) belongs to the Cucurbitacea family, is one of the most admired fruits in tropical countries especially India. The drip irrigation system help growers to use water more resourcefully and in reducing extra expenditure on water and thereafter recording good profits (Donavon et $a l ., 2012$ ). The yield, quality, and water use efficiency of muskmelon are affected by drip irrigation (Danial et al., 2001). Protected cultivation techniques including shade net house technology are known to provide optimum environmental condition for better crop growth and yield with high quality 
produce (Fallik et al., 2009; Shahak et al., 2004; Smith et al., 1984). Mulching is very useful in protecting the roots of the plants from heat, cold. Mulch is used to cover soil surface around the plants to create congenial condition for the growth. This includes temperature moderation, reduce salinity and weed control. It exerts decisive effects on earliness, yield and quality of the crop (Bhardwaj, 2013) Zoran et al., (2011) reported that the colour shade net improves productivity by moderating climatic extremes. In light of the above facts, the present study was undertaken to study the response of muskmelon to spectral modification of shading nets under different drip irrigation regimes during summer season under semiarid condition.

\section{Materials and Methods}

The present investigation was carried out at the Instructional Farm of Department of Irrigation and Drainage Engineering, Dr. Annasaheb Shinde College of Agricultural Engineering \& Technology, Mahatma Phule Krishi Vidyapeeth, Rahuri during the period from February 2017 to June 2017. Geographically, the farm lies at $74^{\circ} 38^{\prime} 00^{\prime \prime} \mathrm{E}$ longitudes and $19^{\circ} 20^{\prime} 00^{\prime \prime} \mathrm{N}$ latitude at $557 \mathrm{~m}$ above the mean sea level, in the central campus of Mahatma Phule Krishi Vidyapeeth, Rahuri. Climatically, the region falls under the semi-arid and sub-tropical zone with average annual rainfall of $566.48 \mathrm{~mm}$.

\section{Experimental details}

The experiment was conducted by adopting spilt factorial design. Shading nets with different colour and shading percentage and open field (control, with no shading) were the main treatments for the experiment. Eight sub treatments (agro-techniques) with three replications were randomized with three replication in each main treatment. The treatment details for the experiments were as under:

Main treatment: Growing environment (Shading percentage and net colour)

$\mathrm{S}_{1:}$ 35\% shading (Green-White shade net)

$\mathrm{S}_{2:}$ 50\% shading (Green -White shade net)

$\mathrm{S}_{3:}$ 75\% shading (Green-White shade net)

$\mathrm{S}_{4:}: 50 \%$ shading (Red shade net)

$\mathrm{S}_{5:}$ 0\% shading (open field)

Sub - treatment: (Agro- techniques: Irrigation levels and mulch)

$\mathrm{T}_{1}$ : Drip irrigation @ 120\% of ETc with plastic mulch.

$\mathrm{T}_{2}$ : Drip irrigation @ 120\% of ETc without plastic mulch.

$\mathrm{T}_{3}$ : Drip irrigation @ 100\% of ETc with plastic mulch.

$\mathrm{T}_{4}$ : Drip irrigation@ $100 \%$ of ETc without plastic mulch.

$\mathrm{T}_{5}$ : Drip irrigation @ 80\% of ETc with plastic mulch.

$\mathrm{T}_{6}$ : Drip irrigation @80\% of ETc without plastic mulch.

$\mathrm{T}_{7}$ : Drip irrigation @ 60\% of ETc with plastic mulch.

T8: Drip irrigation @ 60\% of ETc without plastic mulch

The hybrid variety "Kundan" of muskmelon was grown under shade net (as well as open field). The experimental area of each shade net and the open field was $18 \mathrm{~m} \times 16 \mathrm{~m}$. The size of each plot under each treatment was 3.9 $\mathrm{m} \times 2 \mathrm{~m}$. The media in shade net house consisted of red soil, farm yard manure (FYM) and sand mixed with wheat husk in the proportion of 3:3:3:1 and black cotton soil with textural class "clay" used for control treatment. The $\mathrm{EC}$ and $\mathrm{pH}$ of the media in shade net was $0.42 \mathrm{dSm}^{-1}$ and 7.65, respectively and that for soil in open field were $0.61 \mathrm{dSm}^{-1}$ and 8.3 , respectively. The 
available $\mathrm{N}, \mathrm{P}$ and $\mathrm{K}$ for media in shade net house were $155.93,40.45$ and $225.75 \mathrm{~kg} \mathrm{ha}^{-1}$, respectively and that of for soil in open field was $150.53,46.52$ and $348.5 \mathrm{~kg} \mathrm{ha}^{-1}$ respectively.

\section{Irrigation scheduling}

Climatological approach was adopted for estimating reference evapotranspiration (ETr). The climatological data viz. daily maximum and minimum temperature, daily minimum and maximum relative humidity, wind speed at $2 \mathrm{~m}$. height, actual sunshine hour and rainfall etc. were collected from automatic weather station installed on experimental plot. On the basis of climatological data, amount of water applied for muskmelon crop was estimated. Irrigation with $120 \%, 100 \%, 80$ $\%$, $60 \%$, of ETc was given on daily basis through drip system. The irrigation scheduled was based on the FAO penman- Monteith method to estimate ETr, as presented by equation (1)

$E T r=\frac{0.408 \Delta\left(R_{n}-G\right)+\gamma \frac{900}{T+27 g} u\left(\theta_{g}-\theta_{a}\right)}{\Delta+\gamma\left(1+0.34 u_{2}\right)}$

Where,

ETr - Reference evapotranspiration (mm day $^{-1}$ )

$R_{n} \quad$ - Net radiation at the crop surface $\left(\mathrm{MJ} \mathrm{m}^{-2}\right.$ day $^{-1}$ )

$\mathrm{G}$ - Soil heat flux density (MJ m $\mathrm{m}^{-2}$ day $^{-1}$ )

$\mathrm{T} \quad$ - Mean daily air temperature at $2 \mathrm{~m}$ height $\left({ }^{\circ} \mathrm{C}\right)$

$\mathrm{u}_{2} \quad$ - Wind speed at $2 \mathrm{~m}$ height $\left(\mathrm{m} \mathrm{s}^{-1}\right)$

$\mathrm{e}_{\mathrm{s}} \quad-\quad$ Saturation vapours pressure $(\mathrm{kPa})$

$\mathrm{e}_{\mathrm{a}} \quad$ - Actual vapour pressure $(\mathrm{kPa})$

$\mathrm{e}_{\mathrm{s}^{-}} \quad-\quad$ saturation vapour pressure deficit

$\mathrm{e}_{\mathrm{a}} \quad(\mathrm{kPa})$

$\Delta \quad$ - Slope vapour pressure curve $(\mathrm{kPa}$ ${ }^{\circ} \mathrm{C}^{-1}$ )

$\mathrm{e}_{\mathrm{s}^{-}} \quad-\quad$ Saturation vapour pressure deficit $\mathrm{e}_{\mathrm{a}} \quad(\mathrm{kPa})$

$\gamma \quad$ - Psychometric constant $\left(\mathrm{kPa}^{\circ} \mathrm{C}^{-1}\right)$

The daily crop coefficient required for computing the daily crop evapotranspiration was estimated using the third degree polynomial equation based on $\mathrm{Kc}$ values adopted from FAO bulletin and shown in Eq. (2)

$\mathrm{Kc}_{\mathrm{t}}=-4.649(\mathrm{t} / \mathrm{T})^{3}+5.945(\mathrm{t} / \mathrm{T})^{2}-1.195(\mathrm{t} / \mathrm{T})$ +0.5 ------ (2)

where,

$K c_{\mathrm{t}}=$ Crop coefficient on $\mathrm{t}^{\text {th }}$ day

$\mathrm{t}=$ Number of days since sowing

$\mathrm{T}=$ Total crop growth period (days)

The daily crop evapotranspiration was estimated using Eq.(3) as shown below:

$\mathrm{ETc}=\mathrm{ETr} \times \mathrm{Kc}$

where,

$\mathrm{ET}=$ Crop evapotranspiration $\left(\mathrm{mm} \mathrm{day}^{-1}\right)$

$\mathrm{ETr}=$ Reference crop evapotranspiration $(\mathrm{mm}$ day $^{-1}$ )

$\mathrm{Kc}=$ Crop coefficient

The water requirement of muskmelon crop was estimated using Eq. (4) as shown below:

$\mathrm{WR}=[(\mathrm{ETc} \times$ Irrigation level factor $)-$ Effective Rainfall (mm/day)]

Where

$\mathrm{WR}=$ Water requirement of crop $(\mathrm{mm} /$ day

ETc $=$ Crop evapotranspiration $(\mathrm{mm} /$ day $)$

The irrigation level factor considered as 1.2, 1.0, 0.8, and 0.6 for respective irrigation levels.

Drip irrigation method was adopted for application of the water on daily basis, through its on-line non-pressure compensating emitter spaced $30 \mathrm{~cm}$ spacing 
on a lateral for each crop row. The emitters had a rated discharged of $2 \mathrm{lph}$ at operating pressure of $1 \mathrm{Kg} / \mathrm{cm}^{2}$.

\section{Fertilizer scheduling}

The fertigation tank was used for injecting the fertilizer into the drip irrigation system.

$\mathrm{N}: \mathrm{P}: \mathrm{K} @ 100: 50: 50$ were given as per the schedule shown in Table 1. The fertigation started 15 days after sowing at 2 days interval.

\section{Water use efficiency and fertilizer use efficiency}

The water use efficiency (WUE) for drip irrigation was determined from the muskmelon yield data and the total depth of water applied. It was calculated by using Eq. 5:

Field water use efficiency $=\frac{Y}{W R}$

where,

$\mathrm{Y}=$ Crop yield $(\mathrm{kg} / \mathrm{ha})$

$\mathrm{WR}=$ Total water requirement of crop $(\mathrm{mm})$

The fertilizer use efficiency was calculated by using total quantity of fertilizers applied to each treatment and total yield of the each treatment. The fertilizer use efficiency was determined by using Eq.6:

Fertilizer use efficiency $=\frac{\gamma_{\text {iald }}(\mathrm{kg} / \mathrm{ha})}{\text { Quantity of fortilizer appliad }(\mathrm{kg} / \mathrm{ha})}$ (6)

\section{Results and Discussion}

\section{Soil}

The bulk density, field capacity, permanent wilting point for soil were observed as $1.42 \mathrm{~g}$ $\mathrm{cm}-3,29.63 \%, 19.69 \%$ and that for media in shade net house were $1.29 \mathrm{~g} \mathrm{~cm}-3,22.96 \%$, $17.89 \%$, respectively and seems media in shade net was more porous than the open field. The water holding capacity was higher in clay soil as compared to media of the shed net house.

\section{Climatological data in open field}

The variation between 41.8 to $27.2^{\circ} \mathrm{C}$ was observed for the maximum temperature similarly variation between 26.9 and $9.4^{\circ} \mathrm{C}$ was observed for the minimum temperature varies from throughout the crop growth period. The maximum relative humidity varied from 92 to $20 \%$ and the minimum relative humidity varied from 85 to $7 \%$. The observations of the actual sunshine hours data showed that the highest value of actual sunshine hours is $11.7 \mathrm{hrs}$ whereas the lowest value of actual sunshine hours is $2.3 \mathrm{hrs}$ during the crop growth period. The highest value of wind speed is $9.6 \mathrm{~km} \mathrm{hr}^{-1}$ whereas the lowest value of wind speed is $0.4 \mathrm{~km} \mathrm{hr}^{-1}$, over the crop growth period. The maximum reference evapotranspiration over the crop growth period is $8.13 \mathrm{~mm} \mathrm{day}^{-1}$ while the minimum value is $3.09 \mathrm{~mm} \mathrm{day}^{-1}$. The observation of crop reference evapotranspiration data reveals that the maximum crop evapotranspiration over the crop growth period is $7.67 \mathrm{~mm} \mathrm{day}^{-1}$ while the minimum value is $1.50 \mathrm{~mm} \mathrm{day}{ }^{-1}$. The seasonal crop evapotranspiration was computed as summation of daily reference evapotranspiration and it was found to be $660.83 \mathrm{~mm}$. Higher the value of ETc during the peak crop growth period is due to higher temperature, low relative humidity, higher sunshine hours and greater wind speed (Fig. 1).

\section{Water requirement}

The total net water requirement of muskmelon varied with growing environment, due to different crop period. The highest seasonal water requirement $(564.23 \mathrm{~mm})$ was 
observed in red shade net with $50 \%$ shading at irrigation level of $120 \%$ of $\mathrm{ET}_{\mathrm{c}}$ due to longest crop period. However under green white shade net with $35 \%$ shading at irrigation level of $120 \%$ of $\mathrm{ET}_{\mathrm{c}}$ it was 531.61 $\mathrm{mm}$. and under green white shade net with 50 $\%$ shading and under green white shade net with $75 \%$ shading at irrigation level of $120 \%$ of $\mathrm{ET}_{\mathrm{c}}$ it was $455.01 \mathrm{~mm}$.

The lowest seasonal water requirement (486.27 mm) was observed in open field due to shortest crop period is presented in Table 2.

\section{Biometric observations}

Effect of shading percentage and agro techniques on yield and biometric observation are shown in Table 3. It was observed that green white shade net with $35 \%$ shading had early flowering (26.75 DAS). The red shade net with $50 \%$ shading had highest equatorial diameter $(12.96 \mathrm{~cm})$, polar fruits diameter
(13.41 cm), number of fruits per vine (4.54), weight of fruits (702.20 gm.) and yield (18.40 $\left.\mathrm{t} \mathrm{ha}^{-1}\right)$. The green white shade net with75\% shading had maximum length of vine (4.86 $\mathrm{m})$.

Among different irrigation treatments, treatment $\mathrm{I}_{1}$ i.e. drip irrigation@120\% ETc with silver black plastic mulch recorded early flowering (31.13 DAS), maximum length of vine $(3.55 \mathrm{~m})$, number of fruits per vine (3.77), yield $\left(15.58 \mathrm{t} \mathrm{ha}^{-1}\right)$.

Among different irrigation treatments, treatment $\mathrm{I}_{1}$ i.e. drip irrigation @ 120 \% ETc with silver black plastic mulch recorded early flowering (31.13 DAS), maximum length of vine $(3.55 \mathrm{~m})$, number of fruits per vine (3.77), yield $\left(15.58 \mathrm{t} \mathrm{ha}^{-1}\right)$. The highest dry matter weight of vine $(0.31 \mathrm{Kg})$, length of vine $(3.53$ $\mathrm{m})$, number of fruits (3.58) and yield (14.81 t.ha $^{-1}$ ) was recorded under silver black plastic mulch.

Table.1 Fertilizer dose for muskmelon crop

\begin{tabular}{|c|c|c|c|}
\hline Dose & $\begin{array}{c}\text { No. } \\
\text { of } \\
\text { Splits }\end{array}$ & $\begin{array}{c}\text { Quantity of Fertilizer } \\
\qquad\left(\mathrm{kg} \mathrm{ha}^{-1}\right)\end{array}$ & $\begin{array}{l}\text { Quantity of Fertilizer } \\
\qquad\left(\mathrm{kg} \mathrm{ha}^{-1}\right)\end{array}$ \\
\hline \multirow{2}{*}{$\begin{array}{l}100: 50: 50 \\
(2 \text { days } \\
\text { interval })\end{array}$} & \multirow[t]{2}{*}{25} & 19:19:19 & Urea (46:00:00) \\
\hline & & $\begin{array}{c}263.1579 \mathrm{~kg} \mathrm{ha}^{-1} \\
\left(4.926 \mathrm{~kg} \mathrm{ha}^{-1} / \mathrm{split} \text { or }\right. \\
197.0526 \mathrm{~g} / \\
\text { treatment/split) }\end{array}$ & $\begin{array}{c}108.6957 \mathrm{~kg} \mathrm{ha}^{-1} \\
\left(2.034 \mathrm{~kg} \mathrm{ha}^{-1} / \mathrm{split}^{\text {or }}\right. \\
81.3913 \mathrm{~g} / \text { treatment/split})\end{array}$ \\
\hline
\end{tabular}

Table.2 Seasonal water requirement $(\mathrm{mm})$ of muskmelon crop under different growing environment

\begin{tabular}{|c|c|c|c|c|}
\hline \multirow{2}{*}{$\begin{array}{c}\text { Growing } \\
\text { environment }\end{array}$} & \multicolumn{4}{|c|}{ Irrigation levels } \\
\cline { 2 - 5 } & I1 & I2 & I3 & I4 \\
\hline S1 & 531.61 & 443.01 & 354.41 & 265.81 \\
\hline S2 & 546.01 & 455.01 & 364.00 & 273.00 \\
\hline S3 & 546.00 & 455.01 & 364.40 & 273.30 \\
\hline S4 & 564.23 & 470.19 & 376.15 & 282.12 \\
\hline S5 & 486.27 & 405.22 & 324.18 & 243.13 \\
\hline
\end{tabular}


Table.3 Effect of shading percentage and agro techniques on yield and biometric observation

\begin{tabular}{|c|c|c|c|c|c|c|}
\hline Treatment & $\begin{array}{c}\text { Days to } \\
50 \% \\
\text { Flowering }\end{array}$ & $\begin{array}{l}\text { Avg. } \\
\text { fruits } \\
\text { weight } \\
\text { (gm) }\end{array}$ & $\begin{array}{l}\text { Equatorial } \\
\text { diameter } \\
\text { of fruit } \\
\text { (cm) }\end{array}$ & $\begin{array}{l}\text { Polar } \\
\text { diameter } \\
\text { of fruits } \\
\text { (cm) }\end{array}$ & $\begin{array}{l}\text { Length of } \\
\text { vine at } \\
\text { last } \\
\text { harvesting } \\
\text { (m) }\end{array}$ & $\begin{array}{c}\text { Yield of } \\
\text { fruits } \\
\left.\text { (t.ha- }^{1}\right)\end{array}$ \\
\hline \multicolumn{7}{|c|}{ Growing environment } \\
\hline S1 & $26.75^{\mathrm{c}}$ & $586.41^{\mathrm{a}}$ & $10.98^{\mathrm{a}}$ & $11.90^{\mathrm{a}}$ & $2.65^{\mathrm{a}}$ & $10.41^{b}$ \\
\hline $\mathbf{S 2}$ & $32.33^{b}$ & $624.80^{b}$ & $12.90^{\mathrm{b}}$ & $13.26^{\mathrm{b}}$ & $3.61^{\mathrm{b}}$ & $8.69^{a}$ \\
\hline S3 & $33.04^{b}$ & $609.86^{\mathrm{a}}$ & $12.02^{b}$ & $11.94^{\mathrm{a}}$ & $4.86^{\mathrm{d}}$ & $7.93^{\mathrm{a}}$ \\
\hline S4 & $35.38^{\mathrm{a}}$ & $702.20^{b}$ & $12.96^{\mathrm{b}}$ & $13.41^{b}$ & $4.20^{c}$ & $18.40^{\mathrm{c}}$ \\
\hline S5 & $33.50^{b}$ & $520.78^{\mathrm{a}}$ & $10.09^{\mathrm{a}}$ & $11.29^{\mathrm{a}}$ & $1.77^{\mathrm{a}}$ & $15.35^{\mathrm{c}}$ \\
\hline SE $( \pm)$ & 0.495 & 28.049 & 0.606 & 0.421 & 0.066 & 0.850 \\
\hline CD at $5 \%$ & 1.615 & 91.474 & 1.978 & 1.374 & 0.215 & 2.8 \\
\hline \multicolumn{7}{|c|}{ Irrigation treatment } \\
\hline I1 & $31.13^{\mathrm{b}}$ & 600.44 & 12.38 & 13.03 & $3.55^{\mathrm{b}}$ & $15.58^{\mathrm{d}}$ \\
\hline I2 & $32.43^{\mathrm{a}}$ & 594.60 & 11.62 & 12.09 & $3.49^{b}$ & $13.65^{\mathrm{c}}$ \\
\hline I3 & $32.37^{\mathrm{a}}$ & 663.15 & 11.61 & 12.07 & $3.47^{\mathrm{b}}$ & $11.08^{b}$ \\
\hline I4 & $32.87^{\mathrm{a}}$ & 577.05 & 11.55 & 12.25 & $3.16^{\mathrm{a}}$ & $8.30^{\mathrm{a}}$ \\
\hline SE $( \pm)$ & 0.337 & 41.775 & 0.252 & 0.291 & 0.106 & 0.500 \\
\hline CD at $5 \%$ & 0.952 & NS & NS & NS & 0.300 & 1.410 \\
\hline \multicolumn{7}{|c|}{ Mulch treatment } \\
\hline M1 & 31.92 & 610.62 & 11.78 & 12.51 & $3.53^{b}$ & $14.81^{\mathrm{b}}$ \\
\hline M2 & 32.48 & 607.00 & 11.81 & 12.21 & $3.30^{\mathrm{a}}$ & $9.49^{\mathrm{a}}$ \\
\hline SE $( \pm)$ & 0.239 & 29.539 & 0.178 & 0.206 & 0.075 & 0.354 \\
\hline CD at $5 \%$ & NS & NS & NS & NS & 0.212 & 1.0 \\
\hline \multicolumn{7}{|c|}{ Interaction effect of growing environment and irrigation treatments } \\
\hline SE ( $( \pm)$ & 0.754 & 93.411 & 0.562 & 0.651 & 0.238 & 1.118 \\
\hline CD at $5 \%$ & 2.128 & NS & NS & NS & NS & 3.154 \\
\hline \multicolumn{7}{|c|}{ Interaction effect of growing environment and mulch treatments } \\
\hline SE $( \pm)$ & 0.534 & 66.051 & 0.398 & 0.460 & 0.168 & 0.791 \\
\hline CD at $5 \%$ & 1.505 & NS & NS & NS & NS & NS \\
\hline \multicolumn{7}{|c|}{ Interaction effect of irrigation treatment and mulch treatments } \\
\hline SE $( \pm)$ & 0.477 & 59.078 & 0.356 & 0.412 & 0.150 & 0.707 \\
\hline CD at $5 \%$ & 1.346 & 166.634 & NS & NS & NS & NS \\
\hline \multicolumn{7}{|c|}{ Interaction effect of growing environment and agro-techniques } \\
\hline SE $( \pm)$ & 1.067 & 132.103 & 0.795 & 0.920 & 0.336 & 1.581 \\
\hline CD at $5 \%$ & 3.010 & NS & NS & NS & NS & NS \\
\hline
\end{tabular}


Fig.1 Variation in daily values of crop evapotranspiration

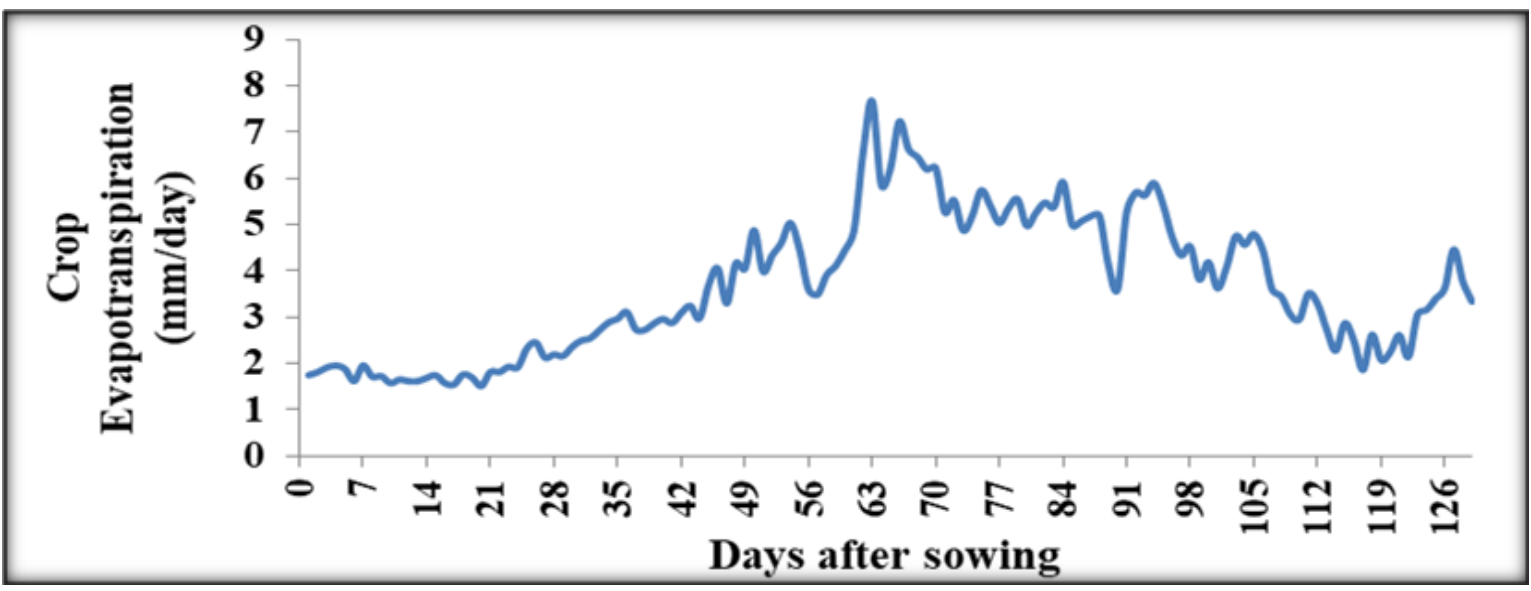

Fig.2 Effect of growing environment on water use efficiency

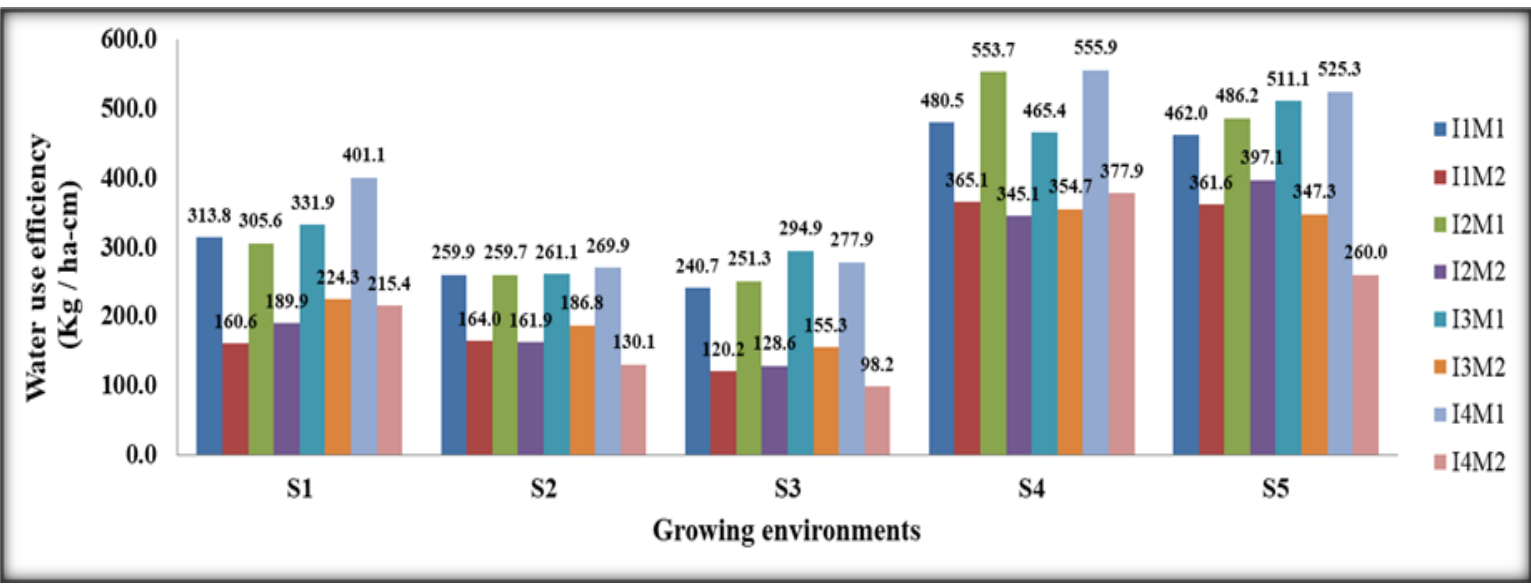

Fig.3 Effect of irrigation treatment on water use efficiency

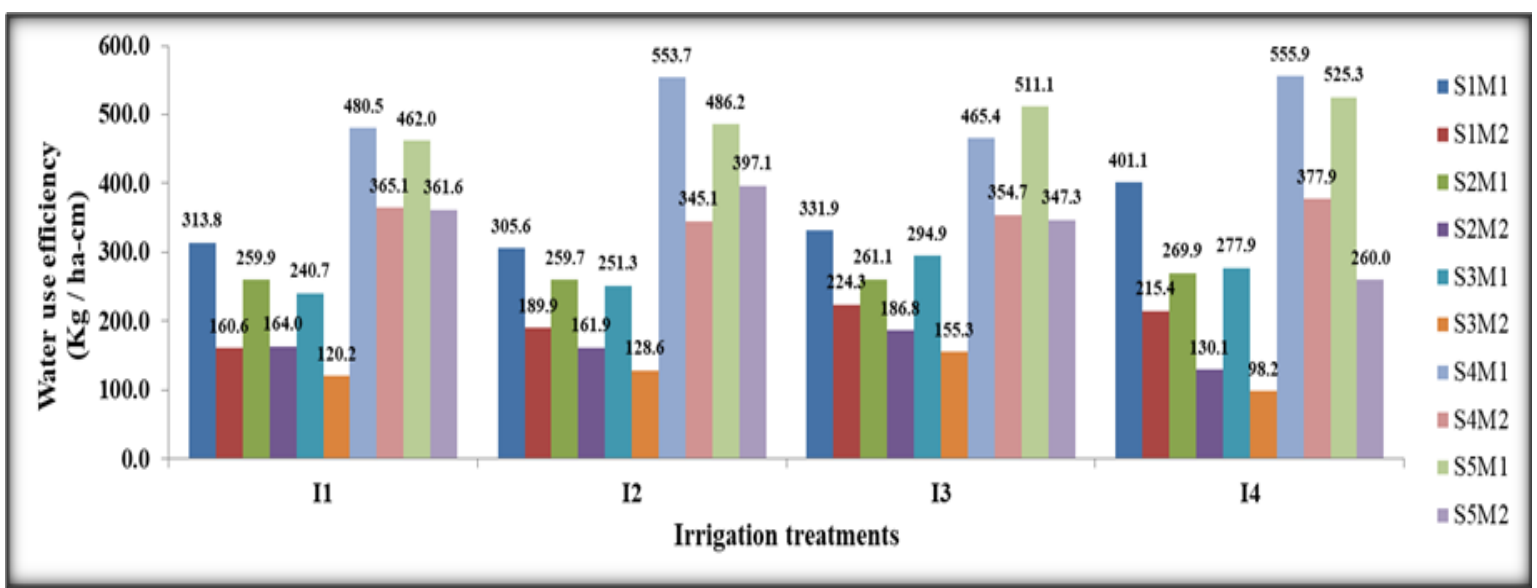


Fig.4 Effect of mulch treatment on water use efficiency

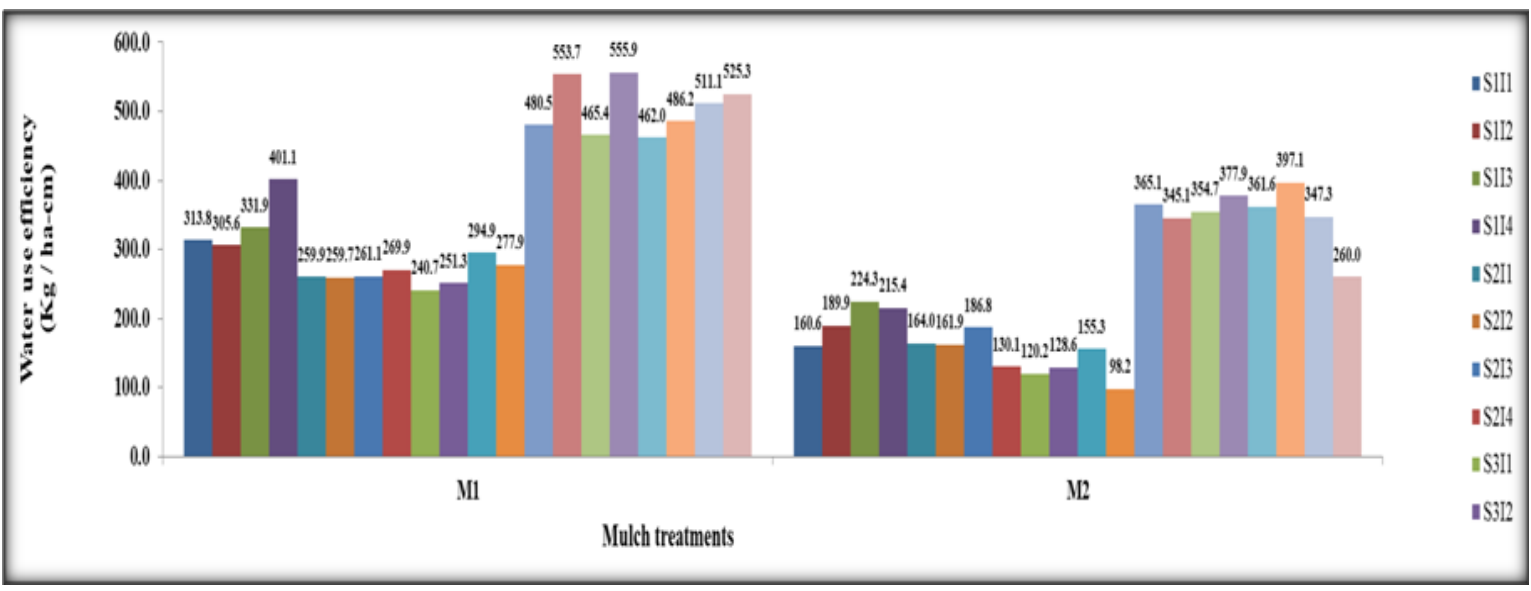

Fig.5 Effect of growing environment on fertilizer use efficiency

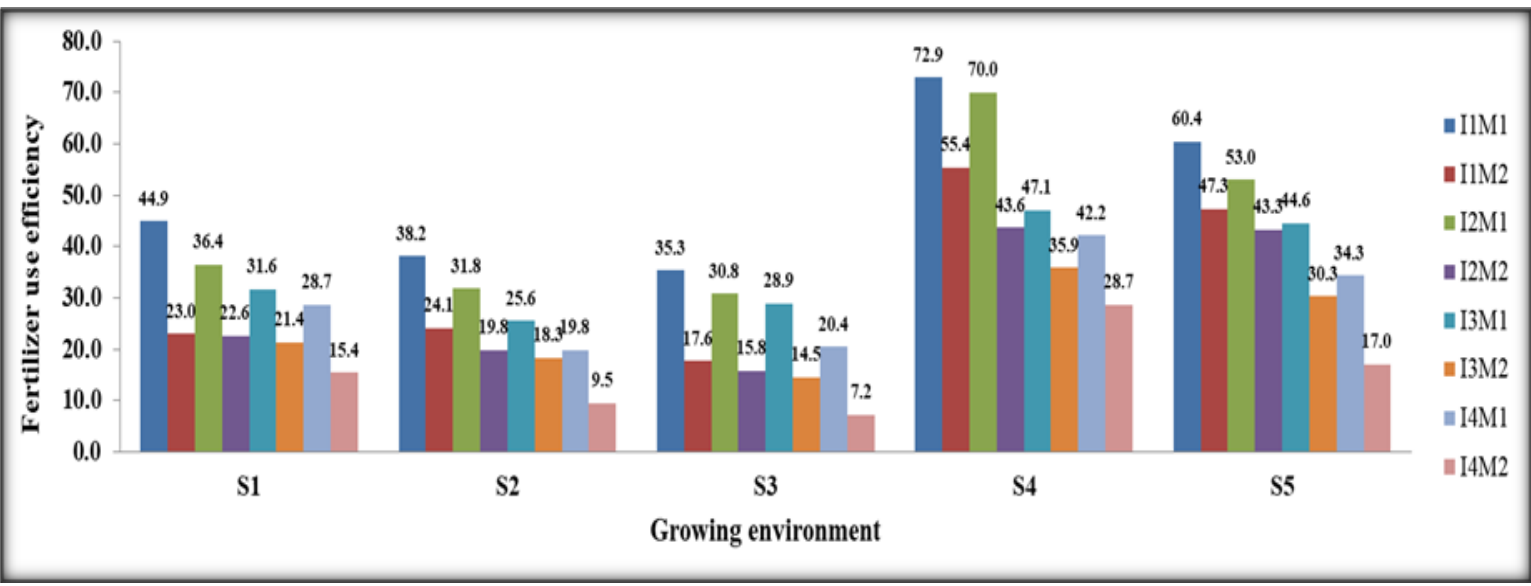

Fig.6 Effect of irrigation treatment on fertilizer use efficiency

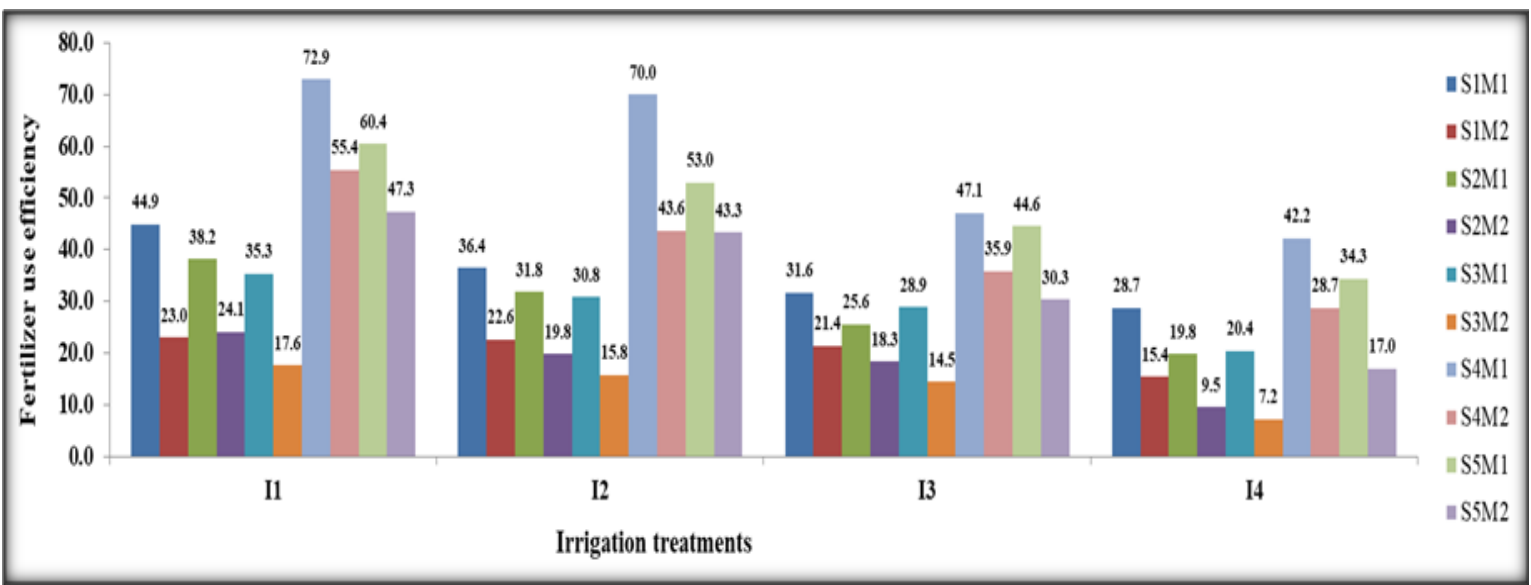


Fig.7 Effect of mulch treatment on fertilizer use efficiency

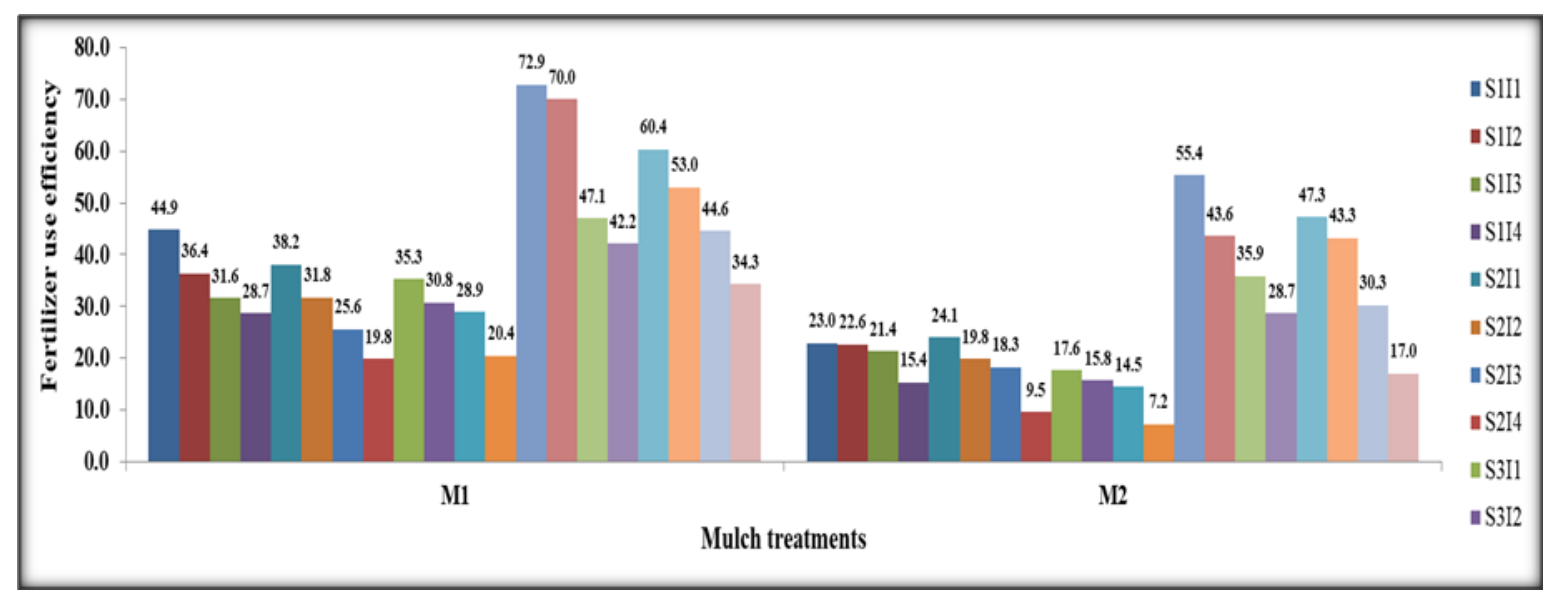

\section{Water use efficiency}

The WUE in green white shade net with 35\% shading percentage varied from 160.5 to $401.14 \mathrm{~kg} / \mathrm{ha}-\mathrm{cm}$ and the maximum WUE was observed in treatment $\mathrm{I}_{4} \mathrm{M}_{1}$.WUE in green white shade net with $50 \%$ shading percentage varied from 130.08 to $269.9 \mathrm{~kg} / \mathrm{ha}-\mathrm{cm}$ and the maximum WUE was observed in treatment $\mathrm{I}_{4} \mathrm{M}_{1}$. WUE in green white shade net with $75 \%$ shading percentage varied from 98.19 to $294.94 \mathrm{~kg} / \mathrm{ha}-\mathrm{cm}$ and the maximum WUE was observed in treatment $\mathrm{I}_{3} \mathrm{M}_{1}$.WUE in open field varied from 259.95 to $525.32 \mathrm{~kg} / \mathrm{ha}-\mathrm{cm}$ and the maximum WUE was observed in treatment $\mathrm{I}_{4} \mathrm{M}_{1}$.WUE in red shade net with $50 \%$ shading percentage was highest and ranged from 345.09 to $555.92 \mathrm{~kg} / \mathrm{ha}-\mathrm{cm}$ and the maximum WUE was observed in treatment $\mathrm{I}_{4} \mathrm{M}_{1}$. The highest WUE was observed in red shade net with $50 \%$ shading $(555.9 \mathrm{~kg} / \mathrm{ha}-\mathrm{cm})$ and irrigation application @ $60 \%$ of ETc under silver black plastic mulch and the lowest WUE was observed in green white shade net with $75 \%$ shading and irrigation application @60\% of ETc without silver black plastic mulch (Fig. 2-4).

\section{Fertilizer use efficiency}

The FUE in green white shade net with $35 \%$ shading percentage ranged from 15.39 to
44.85 and the maximum FUE was observed in treatment $\mathrm{I}_{1} \mathrm{M}_{1}$. FUE in green white shade net with 50\% shading percentage ranged from 9.54 to 38.15 and the maximum FUE was observed in treatment $\mathrm{I}_{1} \mathrm{M}_{1}$ FUE in green white shade net with $75 \%$ shading percentage ranged from 7.21 to 35.33 and the maximum FUE was observed in treatment $\mathrm{I}_{1} \mathrm{M}_{1}$. FUE in open field ranged from 16.99 to 60.40 and the maximum FUE was observed in treatment $\mathrm{I}_{1} \mathrm{M}_{1}$. The FUE in red shade net with 50\% shading percentage ranged from 28.67 to 72.89 and the maximum FUE was observed in treatment $\mathrm{I}_{1} \mathrm{M}_{1}$ (Fig. 5-7).

The highest FUE was observed in red shade net with 50\% shading (72.89) and irrigation application @ 120\% of ETc with silver black plastic mulch and the lowest FUE (7.22) was observed in green white shade net with 75\% shading and irrigation application@ @ $60 \%$ of ETc without silver black plastic mulch.

In conclusion, the highest seasonal water requirement $(564.23 \mathrm{~mm})$ was observed in red shade net with $50 \%$ shading at irrigation level @120\% of ETc due to longest crop period. The maximum yield was observed in red shade net with 50\% shading $\left(\mathrm{S}_{4}\right)(18.40 \mathrm{t}$ $\mathrm{ha}^{-1}$ ) and irrigation application @ $120 \%$ ETc with silver black plastic mulch $\left(15.58 \mathrm{t} \mathrm{ha}^{-1}\right)$. The highest yield $\left(14.81 \mathrm{t} \mathrm{ha}^{-1}\right)$ was recorded 
under silver black plastic mulch $\left(\mathrm{M}_{1}\right)$ as compared to non-mulch treatment. The highest WUE was observed in red shade net with $50 \%$ shading (555.9 kg/ha-cm) and irrigation application @ $60 \%$ of ETc under silver black plastic mulch. The highest FUE was observed in red shade net with $50 \%$ shading (72.89) and irrigation application@ $120 \%$ of ETc with silver black plastic mulch.

Thus it can be concluded that the summer plantation of muskmelon crop under red shade net with $50 \%$ shading with drip irrigation@120\% ETc under silver black plastic mulch is recommended for higher yield under semi-arid conditions of Rahuri, district Ahmednagar of Maharashtra state.

\section{References}

Bhardwaj, and RajuLal2013. Effect of mulching on crop production under rainfed condition - a review. Agri. Reviews, 34(3): 188-197.

Daniel, I. L., J. C. Ward, and R. W. Sprague. 2001. Yield, quality, and water use efficiency of muskmelon are affected by irrigation and transplanting versus direct seeding. Department of Horticultural Sciences, Texas Agricultural Experiment Station, Texas A\&M University, Uvalde. Horti science 36(2): 286-291.

Fallik, E., S. Alkalai-Tuvia, Y. Parselan, Z.
Aharon, A. Elmann, Y. Offir, E. Matan, H. Yehezkel, K. Ratner, N. Zur and Y. Shahak 2009. Can coloured shade nets maintain sweet pepper quality during storage and marketing? Acta Hort. 830: 37-44.

Shahak, Y., E. E. Gussavosky, E. Gal and R. Ganelevin 2004. Colour Nets: crop protection and light quality manipulation in one technology. Proc. VII IS on Prot. Cult. Mild Winter Climates. Acta Hort. 659: 143-151.

Shahak, Y., K. Ratner, N. Zur, Y. Offir, E. Matan, H. Yehezkel, Y. Messsika, I. Posalski and Ben-Yakir, D. 2009. Photoselective netting: An emerging approach in protected agriculture. Acta Hort. 807:79-84.

Shamir, O.M., E.E. Gussakovsky, E. Shpiegel, L.A Nissim, K. Ratner, R. Ovadia, Y. E. Giller and Y. Shahak 2001. Coloured shade nets can improve the yield and quality of green decorative branches of Pittosporum variegatum. J. Hort. Sci. andBiotech. 76: 353-361.

Smith, I.E., Savage, M. J. and Mills, P. (1984). Shading effect on greenhouse tomatoes and cucumber. ActaHort 148:491-500.

Zoran, I., L. Milenkovil, N. Kapoulas. 2011. The effect of colour shade net on the green house climate and paper yield. Original scientific paper, 410(4):201210.

\section{How to cite this article:}

Utkhede, A.D., S.B. Gadge and Gorantiwar, S.D. 2019. Response of Muskmelon to Spectral Modification of Shading Nets under Different Drip Irrigation Regimes. Int.J.Curr.Microbiol.App.Sci. 8(02): 419-428. doi: https://doi.org/10.20546/ijcmas.2019.802.047 